\title{
Epidemiological Studies on Leaf Blight of Sweet Sorghum caused by Exserohilum turcicum (Pass.) Leonard and Suggs
}

\author{
B. M. Kiran*, P. V. Patil and M. M. Sindhu \\ Department of Plant Pathology, College of Agriculture, University of Agricultural Sciences, \\ Dharwad, Karnataka 580 005, India \\ *Corresponding author
}

A B S T R A C T

Ke y w o r d s
Epidemiology,
Leaf blight, Sweet
sorghum,
Exserohilum
turcicum

Sweet sorghum is an important fodder crop, besides which can be used for the multiple purposes like grain, jaggery making and ethanol production. Leaf blight caused by the Exserohilum turcicum is an important disease affecting the sorghum. Studies on epidemiology of the disease were conducted at Main Agricultural Research station, UAS, Dharwad during kharif 2017. Study indicated that, significantly positive correlation was observed with morning and evening relative humidity, rainfall and number of rainy days without any association with maximum and minimum temperature at 0.01 level. Whereas, host range studies indicate that, grain sorghum, bajra, foxtail millet and Johnson grass expressed the symptoms under artificial inoculations with E. turcicum. However, grain sorghum and Johnson grass showed the symptoms under natural conditions also.

\section{Introduction}

Sorghum [Sorghum bicolour (L.) Moench] is a self-pollinated crop belongs to the family poaceae, subfamily panicoidae and tribe andropogoneae. It is one of the main staples for the world's poorest and most foodinsecure people. Among the different types of sorghum like grain and grass sorghum, sweet sorghum [Sorghum bicolour (L.) Moench] is the one which can be used for multi-purpose. It produces food (grain from its ear head), sugary juice and leaves make excellent fodder for animals. Among the foliar diseases affecting the sorghum, anthracnose, leaf blight and grey leaf spot are rampant over in all the humid regions when high rainfall occurs while rust and the sorghum downy mildew are next in importance.

Leaf blight caused by E. turcicum is commonly or generally found on sorghum grown in the sub-tropics and tropical lowlands during summer (Frederiksen, 1982). Occurrence of this pathogen was less consistent in the cooler temperate and tropical 
environments. The pathogen is easily wind disseminated and apparently most consistent in their occurrence and severity across the diverse sorghum growing environments. In India, the disease was first reported by Butler (1918) on the leaves of cultivated sorghum and later by Mitra (1923) from Punjab. The symptoms of leaf blight may vary according to geographical area, host cultivar and pathogen. Yield losses attributed due to this disease will usually vary with sorghum growing region and with environment (Frederiksen, 1982). The sweet sorghum variety SSV 74 was released by University of Agricultural Sciences, Dharwad for kharif season mainly for fodder purpose. This variety is also good for ethanol production and jaggery making. However for the last several years this variety was showing it's susceptibility to the leaf blight caused by $E$. turcicum and causes heavy losses both in fodder and its quality. Even though there are reports of the presence of leaf blight caused by $E$. turcicum on the grain sorghum, no precise information is available on presence of the leaf blight on sweet sorghum and how the epidemiology is influencing disease development in India as well as the world. Keeping this in view, epidemiological study was undertaken to find out how the different weather parameters are influencing the disease and also to find out the host range for the disease.

\section{Materials and Methods}

\section{Correlation of disease with weather parameters}

Experiment was conducted during kharif 2017 at Main Agricultural Research Station, Dharwad under field condition to study correlation of the disease with weather parameters. The highly susceptible sweet sorghum variety SSV 74 was sown in a plot size of $10 \mathrm{~m} \times 10 \mathrm{~m}$. All the agronomic practices were followed to raise the crop.
Observations on leaf blight severity was taken at weekly interval starting from the onset of disease till harvesting of the crop following 09 scale of Mayee and Datar (1986) and further per cent disease index (PDI) was calculated using the formula of Wheeler (1969)and it was used to correlated with weather parameters. Weather parameters were collected from farm section of Main Agricultural Research Station, UAS, Dharwad.

\section{Host range studies of $E$. turcicum}

The weeds and grasses found in fields in and around the Main Agricultural Research Station, UAS, Dharwad and few cultivated crops were included in this study. The weeds and grasses were identified according to Hosmani (1995), Krishnashastry et al., (1984) and Narashimachar (1976).

Above listed hosts (except sugarcane) were raised in $15 \mathrm{~cm}$ diameter pots by using seed or propagating materials. The pots were filled with sterilized soil-sand-FYM mix $(2: 1: 1$ by volume) and placed in a greenhouse at $30 \pm 1^{\circ} \mathrm{C}$. One month old seedlings were sprayed with spore suspension of E. turcicum and covered with polythene bag for $24 \mathrm{hrs}$. Further the inoculated plants were sprayed with water during evening hours to achieve favourable conditions for disease development. Regular monitoring was done to record the observations on symptoms.

\section{Results and Discussion}

\section{Correlation of disease with weather parameters}

Influence of weather parameters on development of the disease

The effect of weather parameters on the severity of leaf blight development was assessed using the susceptible variety SSV 74 
during kharif 2017 at Main Agricultural Research Station, UAS, Dharwad. The intensity of disease was recorded at weekly interval as described in "Material and Methods" and the data were analysed by simple correlation analysis and presented in Table $1 \mathrm{a}, 1 \mathrm{~b}$ and $1 \mathrm{c}$.

The data reveals that, the first appearance of leaf blight disease was observed between $23^{\text {rd }}$ July to $29^{\text {th }}$ July with the PDI of 6.91 per cent ( $30^{\text {th }}$ meteorological standard week).

The PDI was increased from 6.91 to 67.41 per cent as the age of the crop increases. There was sudden increase in PDI from 22.10 to 36.42 per cent between $34^{\text {th }}$ and $35^{\text {th }}$ standard meteorological week because of increase in rainfall, morning and evening relative humidity. It is evident that highest PDI was observed when there is a good rainfall and high relative humidity (morning relative humidity between $95-96 \%$, evening relative humidity between 80- $88 \%$ ). Temperature has not much influenced the disease development since it was almost uniform throughout the cropping season (Table 1a).

\section{Correlation between per cent disease index of leaf blight in relation to weather parameters}

Analysis was made to establish relationship between weather parameters viz., maximum and minimum temperature, morning and evening relative humidity, rainfall and number of rainy days with per cent disease index in susceptible cultivar SSV 74 through correlation.

The relationship between leaf blight severity and weather factors during kharif 2017 (Table $1 \mathrm{~b}$ and $1 \mathrm{c}$ ) indicated that, negative correlation was observed between minimum temperature $(-0.319)$ and maximum temperature (-0.074) whereas, positive correlation was noticed with morning and evening relative humidity, rainfall and number of rainy days. Significantly positive correlation was observed with rainfall (0.709) at 0.05 level. At 0.01 level significantly positive correlation was observed with number of rainy days (0.838), morning (0.778) and evening (0.888) relative humidity. These results are in accordance with Nwanosike et al., (2015) from Tanzania reported that, severity of turcicum leaf blight of maize was significantly positively correlated with the relative humidity, whereas negative correlation was observed with the minimum temperature.

\section{Host range studies of $E$. turcicum}

The possibility of existence of alternative hosts was studied. Twenty two host plants as mentioned in the "Material and Methods" under both artificially inoculated with $E$. turcicum and also natural conditions were examined for their reaction to the pathogen.

The results regarding reaction on different test hosts by the pathogen are presented in Table 2 and it was confirmed that out of 22 hosts, four hosts, viz., grain sorghum (Sorghum bicolour), johnson grass(Sorghum halepense), bajra (Pennisetum glaucum), foxtail millet (Setaria italic) were found to be infected by E. turcicum under challenge inoculations. However, under natural conditions, only two hosts, viz., Sorghum halepense and Sorghum bicolor showed infection. The pathogen could perpetuate during off-season on these alternative hosts and serve as source of secondary infection.

These findings were in accordance with Ullstrup (1966) and Mazzani et al., (1997) who reported that maize leaf blight pathogen E. turcicum also attacked sorghum, sudan grass, johnson grass and teosinte. 
Table.1a Influence of weather parameters on the development of leaf blight

\begin{tabular}{|c|c|c|c|c|c|c|c|c|c|}
\hline \multirow{2}{*}{$\begin{array}{l}\text { Standard } \\
\text { week No. }\end{array}$} & \multirow[t]{2}{*}{ Month and date } & \multirow{2}{*}{$\begin{array}{l}\text { Age of } \\
\text { the crop }\end{array}$} & \multirow{2}{*}{$\begin{array}{l}\text { Per cent } \\
\text { disease } \\
\text { index }\end{array}$} & \multicolumn{2}{|c|}{ Temperature $\left({ }^{\circ} \mathrm{C}\right)$} & \multicolumn{2}{|c|}{ Relative humidity (\%) } & \multirow{2}{*}{$\begin{array}{c}\text { Rainfall } \\
\text { (mm) }\end{array}$} & \multirow{2}{*}{$\begin{array}{l}\text { No. of } \\
\text { rainy } \\
\text { days }\end{array}$} \\
\hline & & & & Maximum & Minimum & Morning & Evening & & \\
\hline 30 & Jul 23-Jul 29 & 21 & 6.91 & 28.1 & 21.2 & 92 & 66 & 4.60 & 0 \\
\hline 31 & Jul 30-Aug 5 & 28 & 11.36 & 28.9 & 20.9 & 91 & 72 & 7.00 & 1 \\
\hline 32 & Aug 6-Aug 12 & 35 & 14.32 & 29.1 & 20.6 & 91 & 65 & 1.00 & 0 \\
\hline 33 & Aug 13-Aug 19 & 42 & 16.17 & 28.6 & 20.5 & 92 & 71 & 8.00 & 1 \\
\hline 34 & Aug 20-Aug 26 & 47 & 22.10 & 28.1 & 20.9 & 96 & 81 & 8.60 & 2 \\
\hline 35 & Aug 27-Sep 2 & 54 & 36.42 & 28.3 & 20.8 & 96 & 80 & 9.20 & 1 \\
\hline 36 & Sep 3-Sep 9 & 61 & 42.32 & 29.7 & 21.4 & 95 & 82 & 73.00 & 3 \\
\hline 37 & Sep 10-Sep 16 & 67 & 55.59 & 29.7 & 21.4 & 96 & 81 & 40.20 & 2 \\
\hline 38 & Sep $17-\operatorname{Sep} 23$ & 74 & 59.17 & 27.0 & 19.8 & 95 & 85 & 12.60 & 3 \\
\hline 39 & Sep 24-Sep 30 & 81 & 67.41 & 28.4 & 20.2 & 96 & 88 & 82.20 & 6 \\
\hline
\end{tabular}


Table.1b Correlation between per cent disease index of leaf blight in relation to weather parameters

\begin{tabular}{|c|c|c|c|c|c|c|c|}
\hline Parameters & $\mathbf{Y}$ & $\mathrm{X} 1$ & $\mathbf{X} 2$ & $\mathbf{X 3}$ & $\mathrm{X} 4$ & X5 & X6 \\
\hline Y-PDI & 1 & -0.074 & -0.319 & $0.709 *$ & $0.838 * *$ & $0.778 * *$ & $0.888 * *$ \\
\hline $\mathbf{X}_{1}-$ Maximum temperature $\left({ }^{\circ} \mathrm{C}\right)$ & -0.074 & 1 & $0.722^{*}$ & 0.381 & -0.100 & -0.105 & -0.171 \\
\hline $\mathbf{X}_{2}$ - Minimum temperature $\left({ }^{\circ} \mathbf{C}\right)$ & -0.319 & $0.722 *$ & 1 & 0.102 & -0.365 & -0.010 & -0.256 \\
\hline $\mathbf{X}_{3}-$ Rainfall & $0.709 *$ & 0.381 & 0.102 & 1 & $0.835 * *$ & 0.531 & 0.659 \\
\hline $\mathbf{X}_{4^{-}}$Rainy days & $0.838^{* *}$ & -0.100 & -0.365 & $0.835 * *$ & 1 & $0.645^{*}$ & $0.860 * *$ \\
\hline $\mathrm{X}_{5}$ - Relative humidity (Morning) & $0.778 * *$ & -0.105 & -0.010 & 0.531 & $0.645^{*}$ & 1 & $0.891 * *$ \\
\hline $\mathbf{X}_{6}$ - Relative humidity (Evening) & $0.888 * *$ & -0.171 & -0.256 & $0.659 *$ & $0.860 * *$ & $0.891 * *$ & 1 \\
\hline
\end{tabular}

*Correlation significant at the 0.05 level

** Correlation significant at the 0.01 level

Table.1c Correlation coefficient (r) for leaf blight severity with weather variables

\begin{tabular}{|l|c|}
\hline \multicolumn{1}{|c|}{ Parameters } & Correlation coefficient \\
\hline Maximum temperature $\left({ }^{\mathbf{0}} \mathbf{C}\right)$ & -0.074 \\
Minimum temperature $\left({ }^{\circ} \mathbf{C}\right)$ & -0.319 \\
Rainfall (mm) & 0.709 \\
Rainy days (days) & 0.838 \\
Relative humidity (morning) $(\boldsymbol{\%})$ & 0.778 \\
Relative humidity (evening) $(\boldsymbol{\%})$ & 0.888 \\
\hline
\end{tabular}


Table.2 Reactions of different weed hosts and cultivated field crops under natural and artificial inoculations of E. turcicum

\begin{tabular}{|c|c|c|c|c|}
\hline \multirow[t]{2}{*}{ Sl. No. } & \multirow[t]{2}{*}{ Weed/cultivated field crops } & \multirow[t]{2}{*}{ Scientific name } & \multicolumn{2}{|c|}{ Appearance of symptoms } \\
\hline & & & Natural condition & $\begin{array}{c}\text { Artificially } \\
\text { Inoculated condition }\end{array}$ \\
\hline 1 & Gini grass (Cv. Samruddhi) & Panicum maximum Jacq. & - & - \\
\hline 2 & Rhodes grass & Chloris gayan Kunth & - & - \\
\hline 3 & Anjan grass (Cv. Bundel Anjan 1) & Cenchrus ciliaris L. & - & - \\
\hline 4 & Deenanath grass (Cv. Bundel 2) & Pennisetum pedicellatum Trinn & - & - \\
\hline 5 & Fodder maize (Cv. South African tall) & Zea mays L. & - & - \\
\hline 6 & Bajra (Cv. ICTP -8203) & Pennisetum glaucum (L.)R. Br. & - & + \\
\hline 7 & Sugarcane (Cv. COM 265) & Saccharum officinarum L. & - & - \\
\hline 8 & Grain sorghum (Cv. M-35-1) & Sorghum bicolor (L.) Moench & + & + \\
\hline 9 & Wheat (Cv. Amruth) & Triticum sp.L. & - & - \\
\hline 10 & Grain maize(Cv. CM 202) & Zea mays L. & - & - \\
\hline 11 & Ragi (Cv. GPU-28) & Eleusine coracana Gaertn. & - & - \\
\hline 12 & Navane(Cv. HMT-100-1) & Setaria italica(L.) P. Beauvois & - & + \\
\hline 13 & Save (Little millet) (Cv. Sukshema) & $\begin{array}{l}\text { Panicum sumatrense Roth ex Roem. \& } \\
\text { Schult. }\end{array}$ & - & - \\
\hline 14 & Baragu (Prosomillet) (Cv. GPUP 8) & Panicum miliaceum L. & - & - \\
\hline 15 & Udalu (Barnyard millet) (Cv. Sushrutha) & Echinocloa crus-galli (L.) Beauv & - & - \\
\hline 16 & Barley (Cv. Jyoti) & Hordeum volgare $\mathrm{L}$. & - & - \\
\hline 17 & Rice(Cv. MTU 1001) & Oryza sativa L. & - & - \\
\hline 18 & Elephant grass (Napier Grass) & Pennisetum purpureum Schumach. & - & - \\
\hline 19 & Johnson grass & Sorghum halepense (L.) Pers. & + & + \\
\hline 20 & Canary grass & Phalaris minor Retz. & - & - \\
\hline 21 & Nut Grass (Jeku) & Cyperus rotundus (L.) & - & - \\
\hline 22 & Bermuda grass (Karake) & Cynodon dactylon (L.) Pers. & - & - \\
\hline
\end{tabular}

+: Symptoms appeared, -: No symptoms 
Whathaneeyaweech et al., (2016) reported that, E. turcicum causing leaf blight of maize has shown the three different kinds of symptoms on twenty two different hosts belonging to the poaceae family including johnson grass, grain sorghum, rice etc.

In conclusion, present investigation revealed that, morning and evening relative humidity, number of rainy days were significantly influencing the disease development and from the host range studies we came to know that, grain sorghum, johnson grass, bajra, foxtail millet were found to be infected by $E$. turcicum under in vitro conditions, whereas Johnson grass and grain sorghum shown the infection under both natural as well as in vitro conditions, so these host may act as secondary source inoculum and alternative hosts during the off season.

\section{Acknowledgement}

The author wishes to thank Professor P. V. Patil, University of Agricultural Sciences, Dharwad, for his sustained interest in this work and the preparation of this paper

\section{References}

Frederiksen, R.A. 1982. Sorghum in the eighties: Proc. Int. Symp. Sorghum. 2-7 Nov. International Crop Research Institute for Semi-arid Tropics. Patancheru, Andhra Pradesh, India. pp. 263-271.

Butler, E.J. 1918. Fungi and Diseases in Plants. Calcutta and Simla, India Thacker, Spink \& Co., Kolkata (India).

Mitra, M. 1923. Helminthosporium species on cereals and sugarcane in India. Part I
Diseases of Zea mays and Sorghum vulgare caused by species of Helminthosporium. Memoirs of the Dept. Agric. India, Botanical Series, 11: 219-242

Mayee, C.D. and Datar, V.V. 1986. Phytopathometry. Technical Bulletin-1 (Special 3), Marathwada Agric. Univ., Parbhani, p. 218.

Wheeler, B.E.J. 1969. An Introduction to Plant Diseases. John Wiley and Sons, Ltd. London, p. 301.

Krishnashastry, K.M., Baraiah, C., Govindu, H.C. and Khaled, T. F. 1984. Weeds of Karnataka. Univ. Agric. Sci., Bangalore, pp. 108-112.

Hosmani, M.M. 1995. Integrated Weed Management in Field Crops. Univ. Agric. Sci., Dharwad, pp. 162-165.

Narashimachar, S. 1976. Plants species of Western Ghats of Karnataka. Manasa Gangotri, Mysore Univ., pp. 49-50.

Nwanosike, M.R.O., Mabagala, R.B. and Kusolwa, P.M. 2015. Effect of northern leaf blight (Exserohilum turcicum) severity on yield of maize (Zea mays L.) in Morogoro, Tanzania. Int. J. Sci. Res.,4 (9): 465-474.

Ullstrup, A.J. 1966. Corn diseases in the United States and their control. Agriculture Handbook No. 199, United States Department of Agriculture, Washington D.C., USA, p. 26.

Mazzani, C., Garrido, M.J. and Rangel, E. 1997. Occurrence of Exserohilum turcicum on sorghum, johnson-grass and sudan grass in Maracay, Venezuela. Fitopatologia Venezolana, 10: 23.

Wathaneeyaweech, S., Sirithunya, P. and Smitamana, P. 2015. Study of the host range of northern corn leaf blight disease and effect of Exserohilum turcicum toxin on sweet corn. J. Agric. Technol., 11: 953963.

\section{How to cite this article:}

Kiran, B. M., P. V. Patil and Sindhu, M. M. 2020. Epidemiological Studies on Leaf Blight of Sweet Sorghum caused by Exserohilum turcicum (Pass.) Leonard and Suggs. Int.J.Curr.Microbiol.App.Sci. 9(04): 321-327. doi: https://doi.org/10.20546/ijcmas.2020.904.038 